\title{
CULTURAL IDENTITY FORMATION \\ OF CANADA UKRAINIANS: AN ATTEMPT \\ OF THE PROBLEM HISTORIOSOPHY
}

\section{Pylypiv V. I.}

\section{INTRODUCTION}

Ukrainian history does not exist outside the history of individual communities that preserve ethnic, religious, linguistic and cultural identity outside their motherland region - Ukrainian diasporas. Each diaspora contributes its unique heritage to the treasury of Ukrainian history. The history of Ukrainians in Canada shows both the great potential of our compatriots and the opportunities that this country provides. This is where one of the largest Ukrainian diasporas lives. For almost 130 years, Ukrainians have been contributing to Canada's development, enriching the country's multicultural landscape and enhancing social, economic and cultural life.

Culture is a conditioned way of individual or collective behavior, rooted in the past and projected into the future. It is cyclical: the present does not exist without the past, and the future is impossible without the present. The cultural specificity of a nation is a set of historical, prehistoric and environmental factors, and the national psyche is a mysterious force that is hidden in national customs, oral traditions and language.

It is this power that is beyond our conscious perception that motivates our behavior and is the trigger of our impulses. The implicit, volatile and often uncertain national character is manifested in all aspects of the national life - both in historical achievements and in tragedies ${ }^{1}$.

\section{Cultural identity formation of Canada's Ukrainians: towards the problem formulation}

Belonging to a particular culture is a social community experience that is objectified and instituted in a particular way of life, distinctive to members

${ }^{1}$ Chyzhevskyi D.A. History of Ukrainian Literature: Fromthe $11^{\text {th }}$ to the Endof the $19^{\text {th }}$ Century. Edited with a foreword by George S. N. Luckyj. Littleton, CO: Ukrainian Academic Press, 1975. 681 p. [in English] 
of the outlined community, and is different from the lifestyle of another community and is unique.

In a psychological context, it promotes a sense of belonging and social uniqueness. Due to its uniqueness, belonging to a particular culture becomes the basis for the ethnic identity formation.

Meaningful and forming the sense essence of culture is symbolic. It can be argued that culture is woven with symbols. The symbols encode the experience of the group, including the stable aspects of that experience. Thus, culture becomes a symbolic pattern of individual community life. Going beyond empirical concreteness, life patterns are idealized through symbolization, imparting meaning and value to the particular experience.

The symbolizing function of culture gives it the impetus to develop. A deep understanding of cultural symbols, their transplantation into the recipient culture, enables to study the stability and variability of cultural patterns of a particular community in synchronous and diachronic aspects, which is extremely important in the context of modern globalization processes.

C. Cooley ${ }^{2}$ and G. Mead ${ }^{3}$ explored the sociocultural world of symbols that provide interpersonal interactions that function in language, culture, and personal structures ${ }^{4}$.

A significant contribution to the knowledge of culture as a world of symbols was made by E. Cassirer". Various spheres of culture were defined by him as symbolic forms and human as a "creature that creates symbols"6.

Symbolic anthropology was developed by L. White ${ }^{7}$, who believed that culture depends on the symbols that human uses as keys to the world ${ }^{8}$.Cultural patterns through the prism of the coding system and myths

${ }^{2}$ Cooley C.H. Human Nature and the Social Order. Cornell University Library, 2009. 438 p. [in English].

${ }^{3}$ Mead G.H. The Individual and the Social Self: Unpublished Work of George Herbert Mead. D.L. Miller (Ed.). University of Chicago Press, 1982. 229 p. [in English].

${ }^{4}$ Cooley C.H. Social Organization: A Study of the Larger Mind. Forgotten Books, 2019. 458 p. [in English].

${ }^{5}$ Cassirer E. The Philosophy of Symbolic Forms. Vol. 2: Mythical Thought. Yale University Press, 1965. 388 p. [in English].

${ }^{6}$ Cassirer E. The Philosophy of Symbolic Forms. Vol. 4: The Metaphysics of Symbolic Forms. Yale University Press, 1998. 264 p. [in English].

7 White L.A. The Science of Culture: A Study of Man and Civilization (Foundations of Anthropology). Percheron Press / Eliot Werner Publications, 2005. 502 p. [in English].

${ }^{8}$ White L.A. The Evolution of Culture. Routledge, 2007. 400 p. [in English]. 
symbolism as culture nucleus were investigated by L. Shynkaruk, V. Shynkaruk ${ }^{9}$, H. Salata, T. Danylova ${ }^{10}$. At present, the phenomenon of the symbol and culture symbolism is attracting more attention and needs to be thoroughly developed. One of the interesting and promising topics is the role of symbols in the formation of cultural identity.

Canadian Ukrainian researchers, such as O. Martynowych and M. Lupul were largely focused on the formation and development of the Ukrainian diaspora in Canada. In their book "Ukrainians in Canada: The Formative Years, 1891-1924", they shed light on the first wave of Ukrainian immigration to Canada in the context of Canadian history of the late XIX and first thirds of XX century ${ }^{11}$.Canadian historian of Ukrainian descent, senator, and initiator of the multiculturalism policy in Canada P. Yuzyk devoted his exploration to the religious life of the Ukrainian community $^{12}$.

A significant contribution to the study of the history of the first Ukrainian immigrants in Canada was made by the famous Canadian researcher J. Petryshyn in his work "Peasants in the Promised Land: Canada and the Ukrainians" ${ }^{\prime 13}$. O. Subtelny had deeply studied the history of Ukrainians in North America ${ }^{14}$.

However, in the territory of modern Ukraine, the history of the Ukrainian diaspora in Canada is being scrutinized or out of Ukrainian researchers' focus, requiring close attention from Ukrainian historians to this phenomenon.

Monographs, scientific articles, periodicals, reports, statistics were used as the research source base for writing the article. The methodological basis of the study is the historical and systematic approach to the study of social

9 Shynkaruk L.V., Salata H.V., Danylova T.V. Dialogue of Cultures: E. HallandF. Kluckhohn. Bulletin of the National Academy of Culture and Arts Management. 2018. № 3. C. 128-133. [in English].

${ }^{10}$ Shynkaruk V.D., Salata H.V., Danylova T.V. Mythas the Phenomenon of Culture. Bulletin of the National Academy of Culture and Arts Management. 2018. № 4. C. 17-22. DOI: doi.org/10.32461/2226-3209.4.2018.152938 [in English].

${ }^{11}$ Martynowych, O. Lupul, M. Ukrainians in Canada: The Formative Years, 1891-1924. CIUS Press. 1991. [in English].

${ }^{12}$ Yuzyk, P., 1982. Religious Life. In: M. Lupul (Ed.). A Heritage in Transition: Essays in the History of Ukrainians in Canada. Toronto : McClelland and Stewart, 143-172. [in English].

${ }^{13}$ Petryshyn, J. Peasants in the Promised Land: Canada and the Ukrainians. Lorimer. 1985. [in English].

${ }^{14}$ Subtelny, O. Ukrainiansin North America: an Illustrated History. University of Toronto Press. 1994. [in English]. 
objects, the interpretative research paradigm, and the integrative anthropological approach. Descriptive and transdisciplinary methods have made it possible to synthesize research results, gained from experts in various fields of knowledge.

During the days of the first Ukrainian settlers in Canada (1891), the Ukrainian diaspora still retains and promotes its cultural values, forming its own cultural tradition. Numerous factors predetermined Ukrainian emigration from Ukraine, and each of the three waves of Ukrainian emigration to Canada differed from one another to the economic situation of the immigrants, their educational attainment, and their political and national orientation.

Ukrainian language, traditional Ukrainian dishes, bright national clothes have become a component of Canadian Ukrainians culture. Today, representatives of Canadian Ukrainians define themselves as part of a thriving cultural community that encourages a sense of belonging, preservation and development of language and traditions, strong political will and interest to Ukrainian art.

As D. Puderak, executive director of Ukrainian Canadian Congress Saskatchewan Provincial Council, notes "today our members are still creators of the nation. Through the preservation and growth of Ukrainian Canadian culture, identity and aspirations $\langle\ldots\rangle$ we have been able to develop strong communities with great civic pride, support immigration efforts, and complement Saskatchewan's vibrant multicultural identity"15.

Ukrainian culture, like any other culture, is imbued with symbols that convey its meaning from one generation to the next. Culture symbols can be of two types - external and internal, that is, visible and invisible. External symbols refer to behavior models or behavior results that are perceived by others. These include dances, diaspora members' gatherings, scenic and linguistic presentations, art objects and more.

Although internal symbols are usually transmitted through external symbols, they are understood mentally or intuitively, and not just merely contemplated. These include beliefs, values, feelings and ideas, such as religious beliefs, political or social values, such as the value of democracy; legends, mythology or history of a particular group, and a sense of group self-identification.

${ }^{15}$ EllD. Ukrainian Cultural Identity Deeply Rooted in Province. Sask Culture. 2011. URL: https://www.saskculture.ca/impact/success-stories/ukrainian-culturalidentity-deeply-rooted-in-province [Accessed: 10. 12. 2019]. [in English]. 
Preserving ethnic identity across all generations does not necessarily mean preserving all the symbols that are contained in the culture. In fact, the ubiquity of a culture does not mean that all its symbols are equally significant or accepted by all the communitymembers. People selectively use cultural symbols. This is especially true of different generations living in a culturally diverse environment.

Third-generation expatriates' representatives can subjectively identify with their national group without even knowing the national language, not practicing national traditions, or not participating in national organizations. Among Ukrainians living on the territory of Canada, three types of visible cultural symbols, such as Ukrainian cuisine, Ukrainian art items (Easter eggs (pysanky), embroidered shirts (vyshyvanky), paintings) and Ukrainian languagethat is taught to children, are the longest preserved and most commonly encountered.

Such stability of cultural symbols is conditioned by the fact that all symbols accepted and shared by the community, relate to the experience of the community itself. All structured symbols are group experience symbols, even if they are created by individuals. Thus, the study of cultural symbols is a study of the group's past experience.

It is important to distinguish between primary and secondary symbols. Primary symbols refer to universal values based on binary oppositions (Good-Evil; Life-Death; Beauty-Ugliness), and provide a unique reflection of them. For example, an endless note on an Easter egg indicates that life is not an easy straightforward path that it consists of both good and evil, but it is possible to move on one side of the crossed line and thus refrain from evil and promote good.

Secondary symbols are the result of reflection on the primary symbols, an attempt to understand how the primary symbol is perceived by the cultural community ${ }^{16}$. Thus, the story about the Christianization of Kyivan Rus or dumy (thoughts) of St. Volodymyr the Great, Taras Shevchenko can be called secondary symbols.

Synoptic symbols can be compared with great artwork, similar, according to C. Jung's words, to "a dream that never, in all its clarity, interprets itself and never has a clear interpretation. No dream claims: "You must" or "Such is the truth"; it reveals the image of how nature grows a

${ }^{16}$ Isajiw W.W. Symbols and Ukrainian Canadian Identity: Their meaning and Significance / Visible Symbols: Cultural Expression Among Canada's Ukrainians. (M.R. Lupul. Ed.). Edmonton, University of Alberta, 1984. P. 119-129. [in English]. 
plant, and we have already been allowed to draw our conclusions from that image ${ }^{17}$.

A descriptive or analytical symbol is explicit - it clearly tells a story that carries a specific group experience but not a synergy of group experiences. Thus, "The Tale of Ihor's Campaign", like dumy, refers to one real episode of our Ukrainian ancestors' experience.

But they have become symbols of Ukrainian identity because they tell about the past of the Ukrainian community. Such symbols are not only literary works, but also other forms of art, for example, a painting by I. Repin "Zaporozhian Cossacks", which is also known as "Zaporozhiansare writing a letter to the Ottoman Empire sultan".

The descriptive symbol may include synoptic symbols: in the picture above, the Cossacks act as such a synoptic symbol.

There are synoptic primary and secondary symbols as well as descriptive primary and secondary symbols.

Synoptic primary symbols ${ }^{18}$ are embroidered shirt (vyshyvanka) ${ }^{19}$, Easter egg and food ${ }^{20}$; synoptic secondary symbols are Taras Shevchenko, Cossacks, Trident, etc. Descriptive primary symbols include many religious doctrines. The story of Adam and Eve as well as the story of Christmas are descriptive primarysymbols. Dumy, "The Tale of Ihor's Campaign" are descriptive secondary symbols.

National identity which based on synoptic primary symbols is retained for much longer than identity that is based on descriptive and secondary symbols. Accordingly, the third-generation of expatriates, discovering their national identity, first actualizes the synoptic primary symbols, which can be identified as archetypal symbols.

As C. Jung emphasized, "archetype is an unconscious content that is changing and understood; it changes under the influence of the individual consciousness on the surface of which it arises"21.

${ }^{17}$ Yunh, C.G. Psychology and Poetic Creativity / The Fate of Art and Culture in the Western European Thought of XX century.Moscow: Renesaance. 1979. [in Russian]

18 Branch R. Pysanky. Ukrainian Canadian Congress. 1976. URL: http://www.uccregina.ca/en/pysanky.htm [Accessed: 10. 12. 2019]. [in English].

19 Hinther R.L., Mochoruk J. (Eds.). Re-Imagining Ukrainian - Canadians : History, Politics, and Identity. University of Toronto Press, 2011. 448 p. [in English].

${ }^{20}$ Lesiv M. From Ritual Object To Art Form: The Ukrainian Easter Egg Pysanka In Its Canadian Context. Folklorica. 2007. Vol. XII. URL: https://journals.ku.edu/ folklorica/article/view/3782/3620 [Accessed: 10. 12. 2019]. [in English].

${ }^{21}$ Yunh, C.G. Archetype and symbol. Moscow : Renesaance. 1991. [in Russian]. 
External (visible) symbols, such as national dishes, artworks, are stored for the longest time period. Therefore, they are primary synoptic symbols. This also applies to the national language, but only in the realm of its primary symbolism, that is, it is not all language, which is a descriptive symbol, but words describing national food, simple greetings, national household names, historical names and names.

Even speaking English, Canadian Ukrainians use transliteration of archetypal Ukrainian names / words, such as bezkonechnyk (a kind of poem), pysanky (Easter eggs).

National dishes, food in general, are one of the most common symbols of goodness and well-being, inherent to all humanity. Food at the subconscious level is associated with early childhood, mother, family and as a symbol, it provides a link between past and present. Food is a symbol that transmits information through taste, smell, touch, sight, sound.

Thus, it symbolically refers to a much wider range of experiences than most other symbols. Since food is a daily activity, it covers the entire life cycle of both the individual and his / her family and the entire national community $^{22}$.

Objects of artistic creativity, such as pysanka (an Easter egg), is a symbol that has a universal human form, a relatively general context, but it is full of unique cultural meaning, and therefore it becomes a symbol of Ukrainian identity. Vyshyvanka (embroidered shirt) is a symbol that has a form common to many cultures, but with a relatively unique context and content, it also symbolizes Ukrainian identity.

Therefore, synoptic primary symbols are the strongest and most striking symbols of national identity because they implicitly contain essential information about the unique experience of the group. This information provides a better connection with its national roots. The group experience of a particular national community is passed on to the next generations through similar cultural symbols that object to specific historical experiences, emerging as the people culture.

G. Hofstede's cultural model (the "onion" model of culture) interprets culture as an onion, the core of which is beyond articulation, and each of the layers represents a specific culture code - it is rituals, heroes and symbols ${ }^{23}$.

${ }^{22}$ Isajiw W.W. Symbols and Ukrainian Canadian Identity: Their meaning and Significance / Visible Symbols: Cultural Expression Among Canada's Ukrainians. (M.R. Lupul. Ed.). Edmonton, University of Alberta, 1984. P. 119-129. [in English].

23 Hofstede's Cultural Onion. Notes on Intercultural Communication. 2013. URL:https://laofutze.wordpress.com/2009/08/28/303/ [Accessed: 10. 12. 2019]. [in English]. 
For a deep understanding of a certain culture, in particular, the culture of Ukraine and world Ukrainians, we need to decipher each of the secultural codes.

And to this day, the "essence" of Canadian Ukrainian national identity reproduces the basic primary experience of a nation, encoded in food (national dishes), objects of artistic creativity, and native language teaching of the children.

Synoptic primary cultural symbols are archetypal symbols. They give meaning and purpose to all elements of culture, acting as a meaning-creative existential-symbolic phenomenon rooted in the unconscious of a particular community. They contribute to the decoding of multiple culture meanings and its unique experience, "translating" the archetype into the language of culture $^{24}$.

Archetypal symbols need to be interacted not only in synchronous but also in diachronic aspect, taking into account the nuances of transmitting information from one generation to another. Quite often, archetypal characters mediate in the intergenerational space, optimizing the dialogue of different generations' representatives.

\section{First wave of Ukrainian immigration to Canada (1891-1914): historical notes}

Preserved archival documents, publications by Ukrainian Canadian historians, memoirs of Ukrainian pioneers and their descendants provide an opportunity to trace in detail the first steps of the Ukrainian diaspora formation in Canada.

Although the idea of immigration to vacant lands was captivating to Ukrainians in the XIX century, their perceptions of the reality and experience of migrants were limited. At that time, Ukraine was divided and occupied by two great imperial powers of East-Central Europe. Greater, or Eastern, Ukraine, which made up about $80 \%$ of Ukraine's territory, was a part of the Russian Empire since 1654. Eastern Ukrainians were engaged in agriculture and lived in small villages.

They belonged to the Orthodox Church and more than $90 \%$ of them were illiterate. The towns and villages of Eastern Ukraine were largely dominated by foreigners who looked upon the poor and illiterate Ukrainian peasant with

24 Shynkaruk, V.,Salata, H., Danylova, T., The dichotomy of "culture civilization" in the Anglo-American and Western European scientific discourse. Bulletin of the National Academy of Culture and Arts Management. 2018. № 2. C. 82-87. [in Ukrainian]. 
unconcealed contempt. At that time, there was a strong and clearly defined class structure in Ukraine.

The Russians formed the state administration, and later, when Ukraine began to develop industrially, thousands of Russian workers settled in the factory and mining towns of Eastern Ukraine.

The landowners were mostly Poles, and the skilled craftsmen and masters were mostly Germans who immigrated to Ukraine during the reign of Catherine $\mathrm{II}^{25}$. The enslaved Ukrainian peasants were at the lowerend of the social scale. By the middle of the XIX century, a demographic explosion occurred in Ukraine and thousands of Ukrainians emigrated from Eastern Ukraine to the Kuban, Caucasus, and at the end of the XIX century, the government began to encourage the colonization of the territories of Central Asia and the Far East.

Western Ukraine, which made up only $20 \%$ of the ethnographic territory of Ukraine, became part of the Austro-Hungarian Empire after the partition of Poland in 1791-1793 and the defeat of the Ottoman Turks along the Black Sea coast.

Seasonal migration was widely practiced in Austria-Hungary. Industrial workers and miners were needed in Prussia, Germany and France. Transcarpathian Ukrainians were the first who traveled to the United States in the 1970 s., to work on the coal mines of Pennsylvania. The first group of Ukrainians from Galicia left their homeland in 1879.

In 1888, slavery was abolished in Brazil, and agricultural workers were in high demand. Captivated by tempting proposals from the Brazilian government for free travel to Brazil and free lands in the jungles of the provinces (states) of Paraná and Santa Catarina, in the 1980s., from 24 to 30,000 poor peasants from Galicia went there. Their hopes were quickly destroyed by radically different climate conditions, tropical diseases, hard work on plantations and corrupt bureaucracy ${ }^{26}$.

Residents of Western Ukraine were forced to emigrate in large numbers for various reasons. The demographic explosion led to the fact that small farms belonging to the peasants could not be divided among all, while land was the only means of subsistence. Agricultural activity on small farms was

25 Duravetz, G. The Ukrainian Canadians. The Ukrainian Canadianmagazine. 1988. p. 24-29. [in English].

26 Gerus, O. The Ukrainian Canadians. A Community Profile: 1891-2000. Centrefor Ukrainian Canadian Studies. University of Manitoba. 2000. http://umanitoba.ca/faculties/arts/departments/ukrainian_canadian_studies/outreach/3 875.html [Accessed: 01.05.2019]. [in English]. 
primitive, inefficient and labor-intensive, and productivity was low. Large areas of the best farmlands belonged to landowners or the church.

The cities and villages of Western Ukraine were administrative and commercial centers that didn't have an industry or manufacturing base that could reach a large number of employees. Production existed in the form of artisans groups who produced small items required to meet the immediate needs of the local population.

Employment was seasonal, wages - low and unemployment level - high. A large number of landless peasants were forced to work only for food and shelter. German, Polish and Yiddish sounded in the cities, so the Ukrainian peasant felt himself a foreigner in his country.

At the end of XIX century, Canada was experiencing an intense period of economic growth. Construction and mining industry, logging and especially agriculture required large numbers of workers. The completion of the transcontinental railroad in 1885 opened the Canadian West for settlement and provided an opportunity to transport wheat and other agricultural products to eastern markets and port cities. The Canadian government has launched an intensive immigration program aimed at quick settlement of Canadian prairies with active farmers.

Immigration propaganda has hit a very fruitful ground. At this time, Western Ukraine, which was the focus of the campaign, was experiencing severe political and economic oppression. After hearing about virtually free land and political and economic freedoms in Canada, a large number of peasants begun to turn to immigration centers.

Stable transportation provided a constant flow of immigrants to established communities and fostered the emergence of new communities in northern areas. The cultural life of the community was formed around a church, school, or cultural center.

Statistics show that from 1891 to the First World War, 100 to 170,000 Ukrainian migrants arrived in Canada (regarding these differences, the researchers believe that they are the result of a mismatch of birthplace and ethnic origin $)^{27}$.

By 1895, the settlers could choose the location of their estates themselves. Later decisions were made by immigration officials, which often led to confrontation. The lack of financial resources prevented immigrants from buying fertile land. The mistake of the Canadian immigration

${ }^{27}$ Kowcz-Baran, A.M. Ukrainian Catholic Churches of Winnipeg Archeparchy. Saskatoon, SK : Archeparchy of Winnipeg. 1991. [in English]. 
authorities was to believe that Ukrainians came from the steppes of Central Ukraine, similar to the prairies of Western Canada.

However, western Ukraine's woodland area is more similar to Southern Ontario in terms of terrain and climate. The first Ukrainian settlers in Western Canada suffered greatly from hot summers, cold, harsh winters, and the loneliness of living on the prairies.

In addition, they were unprepared for large-scale mechanized grain farming that became profitable in Western Canada. Many newcomers received their estates on heavily wooded lands on the north prairies.

In the winter, men worked in timber farms or coal mines. In her interview, Ukrainian Canadian Mari Romanyuk notes that most miners were Slavic, and many were Ukrainian. Miners were paid \$ 1.80 to \$ 2 per shift. In the summer, the miners worked only three days a week, but from November to June, they worked a full week ${ }^{28}$.

In the summer, men were hired to build a railroad that stretched across all Western Canada. Working hours were long (10-12 hours) and wages were low (10-25 cents per hour). Employing on foreign farms or railroads, deprived of any government assistance and long-term loans that did not exist then, Ukrainian pioneers were forced to leave their families without even the most necessary survival items.

Here is what one of the Ukrainian happiness searchers by seas mentions:

"As I was a peasant who had no trade, I could only work hard for a meager wage. If there were no jobs in Winnipeg, then like the others, I worked on the railroad. We traveled by freight trains from one place to another. I remember that I worked in Vineyard, Saskatchewan, where the boss treated us so roughly that we got fired. One day, some of us walked many miles to getto Yorkton, where, as was said, there was work.

However, when we got there tired and hungry, we were told that we arrived too late and that there was no work for us. Freight trains travels have become a part of our lives, but we have often been driven out of them" 29 .

The problems of the Ukrainians did not end after their arrival in Canada: they were faced with a culture shock and a difficult adaptation to a foreign culture. Being native to the countryside of one of the most undeveloped

${ }^{28}$ Swyripa, F.A. Oral Sources for Researching Ukrainian Canadians. A Survey of Interviews, Lectures and Programmes Recorded to December 1980. Edmonton: Canadian Institute of Ukrainian Studies. The University of Alberta. 1985. [in English].

${ }^{29}$ Myron Kostaniuk reflects. The Ukrainian Canadian Magazine. 1990. [Online]. Available from: https://tc2.ca/sourcedocs/uploads/history_docs/Immigration/ conditions-for-early-ukrainian-immigrants.pdf. [Accessed: 01.05.2019]. [in English]. 
regions of Europe, they shocked Anglo-Saxon Canadians, who perceived Ukrainians as primitive and ungraceful.

After a long journey upon arrival to Halifax, Quebec City and Montreal, exhausted from the trip and uncleaned people came to the ground, many of whom were dressed in the national attire of their region, someone was even barefoot. Their strange clothing, incomprehensible language, lack of personal hygiene skills and excessive garlic consumption did not appeal to Canadian hosts. English newspapers in the east of Canada began to publish offensive articles about the unsuitable fitness of these "Galician in sheepskin coats".

In a letter published in "The Winnipeg Telegram" dated August 10, 1899, the arrival of Ukrainians was portrayed almost as a disaster:

"Among the respectable English-speaking settlers, the possibility of being surrounded by a colony of Russian serfs [Ukrainians] and the realization that, if they remain in their homestead [a farm site, usually 160 acres], they probably will not have other neighbors for them and their family all their life. They experienced all the difficulties of a pioneer existence in the hope of building a comfortable home for themselves and their children.

They chose Canadian North West for their home because of the fact that the British flag hovered over it, and because, as a Canadian, Englishman, Irishman or Scotsman, they wanted to remain British among the British. The settler loser was surrounded by hordes of people slightly better than savages, an alien race, language and religion, whose customs repelled him and whose morals he hated $\langle\ldots\rangle$ all hopes of further development of the British settlement disappear; he becomes a foreigner in his own country. There was nothing left for him except for the frustrating life-long exile on British soil, like deportation to a Siberian settlement" ${ }^{\text {30 }}$.

C. Sifton was criticized for promoting Ukrainian immigration to Canada. Many Canadians' reaction to his immigration policy was negative as Canada was part of the British Empire, and English Canadians expected them to maintain ties with their homeland. Responding to this attack, C. Sifton made his famous statement:

"When I talk about quality, I mean something completely different than the average writer or rapporteur on immigration. I think a hardy peasant in sheepskin born on a land whose ancestors have been farmers for ten

30 It must be thoroughly disheartening..., 1899. The Winnipeg Telegram. [Online]. Available from: https://tc2.ca/sourcedocs/uploads/history_docs/ Immigration/conditions-for-early-ukrainian-immigrants.pdf [Accessed: 01.05.2019]. [in English]. 
generations, with a strong wife and half a dozen children of good quality $<$... I don't care if he was born in Britain".

The Canadian government's belief in the ability and endurance of Ukrainian settlers was justified. The Ukrainians ranked among the first pioneers to help develop much of Western Canada.

Anglo-Saxon authorities have argued that Ukrainian immigrants will be assimilated

Within one or two generations, but this has not happened. Having established their settlements, Ukrainians kept their language, customs and religious traditions. Due to their large numbers, they even assimilated other less numeral Slavs, such as Poles and Russians.

The vast majority of Ukrainian immigrants were Greek Catholics. In peasant Ukrainian culture, the natural rhythms of birth, marriage, and death are religious holidays, reflecting an intense sense of community, so clergy were extremely important for the survival of the group.

Churches, in addition to providing spiritual comfort and performing religious rites, were the cornerstone of Ukrainian language and culture in Canada. Attempts by Canadian Protestant churches, such as Anglicans, Methodists, and Presbyterians, to attract large numbers of Ukrainians have failed.

Among the early migrants was a group whose representatives supported the Ukrainian Radical Party, founded in 1890 by I. Franko and M. Pavlyk. By the 1900s, they had set up reading rooms in different parts of Canada. In 1906, the Shevchenko Society was formed in Winnipeg. It had a library and a reading hall, held cultural, educational and social events. It consisted of former members of the Radical Party of Ukraine, socialists and so-called populists. Its political orientation was socialist and anti-clerical.

In 1905, the Socialist Party of Canada emerged, which included many Ukrainians. In 1907, there were three Ukrainian branches of the Socialist Party of Canada - in Winnipeg and Portage-la-Prairie, Manitoba and Nanaimo, British Columbia. The same year, the Ukrainian Socialists, led by P. Krat, V. Holovatskyi, and M. Stechyshyn, decided to publish the first Ukrainian socialist newspaper on the North American continent. "Red Banner" appeared on November 15, 1907, and lasted until August 8, 1908. It was the Ukrainian socialists who first used the name "Ukrainian", while all other groups used the name "Russian or Rusyn".

"Prosvita" (Enlightenment) reading room was opened in Leydwood, Manitoba in 1908, and the Ukrainian National Association (People's House) was established in Winnipeg in 1913, becoming one of Canada's leading cultural and educational institutions. Although both organizations sought to be non-denominational, "Prosvita" attracted Ukrainian Catholics and 
Uniates and the People's House - Orthodox. Both institutions still exist in many urban and rural centers in Western Canada. The mediators between the Ukrainian migrants and the English-speaking world were a school teacher and a priest who had an education and knowledge of English; it has earned them respect and leadership in the community.

\section{CONCLUSIONS}

Through hard work, Ukrainian settlers in Canada have transformed the Canadian prairies into fertile fields, made significant contributions to the construction of railroads and roads, the development of commercial enterprises, the establishment of educational and cultural centers, and actively participated in the political life of their new homeland.

The descendants of these heroes of the first wave of immigration of Ukrainians to Canada continue to contribute to the development of the country, without losing their spiritual connection with the nanny-Ukraine.

Archetypal cultural symbols make an invaluable contribution to the process of national identification, acting as one way of understanding and interpreting the outside world. For Canadian Ukrainians, they are embodied in national cuisine, artistic works and mo0ther tongue. Due to these symbols, Ukrainians are aware of their belonging to a particular national and cultural group, their destination in the world, as well as form their own life strategies.

Despite the difficult conditions, life gradually brought more pleasure. Residents of Ukrainian settlements could rely on each other during the crisis. Communication in the native language quenched the pain and feeling of loneliness on the new land. The church played an important role in the assimilation of aliens. Church domes against the backdrop of the Canadian prairies have become a symbol of the earthly ambitions of people who have dreamed of free lands all their lives.

\section{SUMMARY}

Ukrainian history does not exist outside the history of individual communities that preserve ethnic, religious, linguistic, and cultural identity outside their motherland region- Ukrainian Diasporas. The history of Ukrainians in Canada shows both the great potential of our compatriots and the opportunities this country provides. The aim of the study is to analyze the place and role of archetypical cultural symbols in the formation of Canadian Ukrainians cultural identity. Methodology of the study. The author has used the descriptive, hermeneutic, cultural-historical, and integrative approaches. The scientific novelty. Synoptic primary cultural symbols are archetypal symbols. They contribute to the decoding of cultural meanings plurality and its unique experience "translating" the archetype into the 
language of culture. It is necessary to interact with archetypical symbols not only in the synchronous, but also in the diachronic aspect taking into account the nuances of information transmission from one generation to another. Conclusions. Archetypical cultural symbols contribute greatly to the process of national identification, being at the same time one of the ways of understanding and interpreting the surrounding world. For Canadian Ukrainians, they are embodied in the national cuisine, artistic works, and mother tongue. Due to these symbols, Ukrainians are aware of their belonging to a particular national and cultural group, their destination in the world, as well as form their own life strategies.

\section{REFERENCES}

1. Branch R. Pysanky. Ukrainian Canadian Congress. 1976. URL: http://www.uccregina.ca/en/pysanky.htm [Accessed: 10. 12. 2019]. [in English].

2. Cassirer E. The Philosophy of Symbolic Forms. Vol. 2: Mythical Thought. Yale University Press, 1965. 388 p. [in English].

3. Cassirer E. The Philosophy of Symbolic Forms. Vol. 4: The Metaphysics of Symbolic Forms. Yale University Press, 1998. 264 p. [in English].

4. Chyzhevskyi D.A/ History of Ukrainian Literature: Fromthe $11^{\text {th }}$ to the Endof the $19^{\text {th }}$ Century. Edited with a foreword by George S. N. Luckyj. Littleton, CO: Ukrainian Academic Press, 1975. 681 p. [in English].

5. Cooley C.H. Human Nature and the Social Order. Cornell University Library, 2009. 438 p. [in English].

6. Cooley C.H. Social Organization: A Study of the Larger Mind. Forgotten Books, 2019. 458 p. [in English].

7. Duravetz, G. The Ukrainian Canadians. The Ukrainian Canadianmagazine. 1988. p. 24-29. [in English].

8. EllD. Ukrainian Cultural Identity Deeply Rooted in Province. Sask Culture. 2011. URL: https://www.saskculture.ca/impact/successstories/ukrainian-cultural-identity-deeply-rooted-in-province [Accessed: 10. 12. 2019]. [in English].

9. Gerus, O. The Ukrainian Canadians. A Community Profile: 18912000. Centrefor Ukrainian Canadian Studies. University of Manitoba. 2000. http://umanitoba.ca/faculties/arts/departments/ukrainian_canadian_studies/o utreach/3875.html [Accessed: 01.05.2019]. [in English].

10. Hinther R.L., Mochoruk J. (Eds.). Re-Imagining Ukrainian Canadians: History, Politics, and Identity. University of Toronto Press, 2011. 448 p. [in English]. 
11. Hofstede's Cultural Onion. Notes on Intercultural Communication. 2013. URL:https://laofutze.wordpress.com/2009/08/28/303/ [Accessed: 10. 12. 2019]. [in English].

12. Isajiw W.W. Symbols and Ukrainian Canadian Identity: Their meaning and Significance / Visible Symbols: Cultural Expression Among Canada's Ukrainians. (M.R. Lupul. Ed.). Edmonton, University of Alberta, 1984. P. 119-129. [in English].

13. It must be thoroughly disheartening..., 1899. The Winnipeg Telegram. [Online]. Available from: https://tc2.ca/sourcedocs/uploads/ history_docs/Immigration/conditions-for-early-ukrainian-immigrants.pdf [Accessed: 01.05.2019]. [in English].

14. Kowcz-Baran, A.M. Ukrainian Catholic Churches of Winnipeg Archeparchy. Saskatoon, SK: Archeparchy of Winnipeg. 1991. [in English].

15. Lesiv M. From Ritual Object To Art Form: The Ukrainian Easter Egg Pysanka In Its Canadian Context. Folklorica. 2007. Vol. XII. URL: https://journals.ku.edu/folklorica/article/view/3782/3620 [Accessed: 10. 12. 2019]. [in English].

16. Marunchak, M. The Ukrainian Canadians. 1982. Vol. 1. Ukrainian Academy of Arts and Sciences (UVAN) in Canada. [in English].

17. Martynowych, O. Lupul, M. Ukrainians in Canada: The Formative Years, 1891-1924. CIUS Press. 1991. [in English].

18. Mead G.H. The Individual and the Social Self: Unpublished Work of George Herbert Mead. D.L. Miller (Ed.). University of Chicago Press, 1982. 229 p. [in English].

19. Myron Kostaniuk reflects. The Ukrainian Canadian Magazine. 1990. [Online]. Available from: https://tc2.ca/sourcedocs/uploads/history_docs/ Immigration/conditions-for-early-ukrainian-immigrants.pdf. [Accessed: 01.05.2019]. [in English].

20. Petryshyn, J. Peasants in the Promised Land: Canada and the Ukrainians. Lorimer. 1985. [in English].

21. Shynkaruk L.V., Salata H.V., Danylova T.V. Dialogue of Cultures: E. HallandF. Kluckhohn. Bulletin of the National Academy of Culture and Arts Management. 2018. № 3. C. 128-133. [in English].

22. Shynkaruk V.D., Salata H.V., Danylova T.V. Mythas the Phenomenon of Culture. Bulletin of the National Academy of Culture and Arts Management. 2018. № 4. C. 17-22. DOI: doi.org/10.32461/22263209.4.2018.152938 [in English].

23. Shynkaruk, V., Salata, H., Danylova, T., The dichotomy of "culture civilization" in the Anglo-American and Western European scientific discourse. Bulletin of the National Academy of Culture and Arts Management. 2018. № 2. C. 82-87. [in Ukrainian]. 
24. Sifton, C. The Immigrants Canada Wants. Maclean's magazine. 1922. p. 32-34. [in English].

25. Subtelny, O. Ukrainiansin North America: an Illustrated History. University of Toronto Press. 1994. [in English].

26. Swyripa, F.A. Oral Sources for Researching Ukrainian Canadians. A Survey of Interviews, Lectures and Programmes Recorded to December 1980. Edmonton : Canadian Institute of Ukrainian Studies. The University of Alberta. 1985. [in English].

27. White L.A. The Evolution of Culture. Routledge, 2007. 400 p. [in English].

28. White L.A. The Science of Culture: A Study of Man and Civilization (Foundations of Anthropology). Percheron Press / Eliot Werner Publications, 2005. 502 p. [in English].

29. Yunh, C.G. Archetype and symbol. Moscow : Renesaance. 1991. [in Russian].

30. Yunh, C.G. Psychology and Poetic Creativity / The Fate of Art and Culture in the Western European Thought of XX century.Moscow : Renesaance. 1979. [in Russian].

31. Yuzyk, P., 1982. Religious Life. In: M. Lupul (Ed.). A Heritage in Transition: Essays in the History of Ukrainians in Canada. Toronto : McClelland and Stewart, 143-172. [in English].

\section{Information about author:}

Pylypiv V. I.,

Candidate of Historical Sciences, Associate Professor, Rector

Kyiv University of Culture 20, Chyhorina St., 01042 Kyiv, Ukraine 